\title{
The globalization of the world coal market - contradictions and trends
}

\author{
Yevheniia Sribna ${ }^{1 *}$, Olena Trokhymets ${ }^{2}$, Ihor Nosatov $^{2}$, and Iryna Kriukova ${ }^{3}$ \\ ${ }^{1}$ National University of Water Environmental and Engineering, 11 Soborna St., 33000 Rivne, Ukraine \\ ${ }^{2}$ Classic Private University, 70B Zhukovskoho St., 69002 Zaporizhzhia, Ukraine \\ ${ }^{3}$ Odessa State Agrarian University, 13 Panteleimonivska St., 65012 Odesa, Ukraine
}

\begin{abstract}
The article describes the global coal market as the ratio of demand and supply depending on the development of energy technologies in the historical section. The continental specificity of coal mining is given. The basic world exporters and importers of coal and their role in the sale of energy fuels are analyzed. The key coal producing countries are China, India, the USA, and Australia. The largest consumers of coal products are China, India, Japan and Korea. There are unconditional leaders in the export coal market: Indonesia and Australia. In addition, a comparison of large coal companies and their share in the world market is presented. The features of coal supplies are analyzed in accordance with international rules (Incoterms), which regulate the rights and obligations of the buyer when conducting international trade, as well as determine the moment of transfer of risks from the seller to the buyer. The following supply bases were characterized: FOB (Free On Board), FAS (Free Alongside Ship), CIF (Cost Insurance and Freight), DAP (Delivered At Place), FCA (Free Carrier) etc. Trends in the logistics component of the global coal industry are revealed. Logistic of coal supply chains in comparison with other energy fuels and their features are disclosed. The problem of profitability of mines and their effectiveness is presented. Assessment of the environmental components of coal use in industry and energy is analyzed. It was noted that on the background of the trend to protect the environment and promote renewable energy, coal is becoming less popular in developed countries. This trend is further exacerbated by state subsidies for green energy.
\end{abstract}

\section{Introduction}

Coal is a traditional form of energy fuels, which is sufficiently distributed in most countries of the world. The whole industrial revolution was based on the extraction and processing of coal. During this period, coal mining and its implementation have formed a single administrative-economic space with the relevant world exchanges and an extensive transport and logistics infrastructure, which defines as a single global market. With the development of fundamental-practical studies of the physics of the structure of the atom

\footnotetext{
*Corresponding author: evsribna@nuwm.edu.ua
} 
and the introduction of nuclear power plants, the role of coal has significantly decreased in the energy sector.

It was the first technological stage in the reorganization of the coal industry, when the coal mines began to be massively closed and the volume of coal mines reduced (for example, England during the reign of $\mathrm{M}$. Thatcher). The next step was the ecological stage for reducing $\mathrm{CO}_{2}$ emissions into airspace and targeting energy sources to renewable energy sources (solar, wind, bioenergy, etc.).

Therefore, the modern coal industry faces urgent problems regarding the volumes and technologies of coal mining, the use of aggregate rocks and their enrichment, as well as the ultimate ecological use of coal.

The purpose of the study is to assess the trends of the coal market in line with the global challenges of pressing environmental requirements. The following tasks were formed according to the purpose:

1. To analyze the dynamics of production and sale of world coal mining.

2. To evaluate the priorities of the world power industry regarding the use of coal in the acquisition of electric current and the impact on the formation of world prices for the sale of coal.

3. To study ecological problems of coal industry and trends in their development.

\section{Analysis of the dynamics of production and sale of coal}

Despite the technological development and development of chemical industry, coal remains the substitute for natural resource for humanity. The geography of its mining is quite extensive and rich, amounting to over 165 billion tons of energy coal, controlled by 135 companies, 117 of which are listed on the stock exchanges of the world (Fig. 1). More than $29 \%$ of power plants in the world operate on the basis of coal.

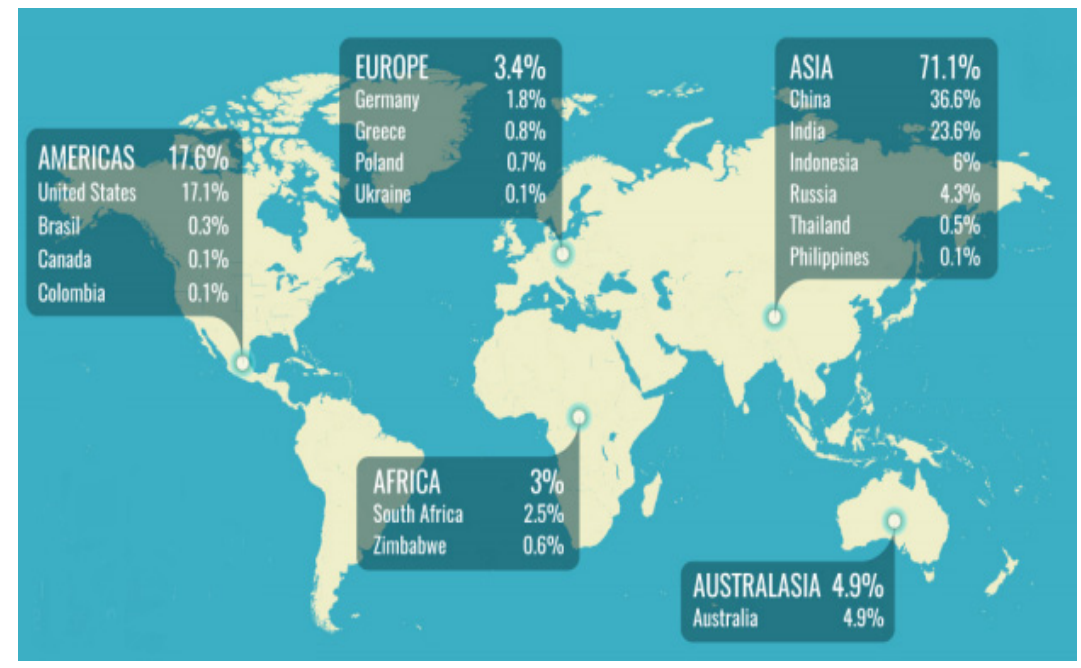

Fig. 1. Distribution of coal reserves in the world [1].

In 2018 , the value of coal exports amounted to $\$ 127.6$ billion. The US, ie, increased by $27.3 \%$ compared with 2014 , when the volume amounted to $\$ 100.2$ billion (Table 1). 
Table 1. World Exporting Countries of Coal in 2018.

\begin{tabular}{|c|l|c|c|}
\hline No. & \multicolumn{1}{|c|}{ Country } & $\begin{array}{c}\text { Export volumes of coal, } \\
\text { billion dollars }\end{array}$ & $\begin{array}{c}\text { Share of total exports } \\
\text { of coal, \% }\end{array}$ \\
\hline 1 & Australia & 47.0 & 36.9 \\
\hline 2 & Indonesia & 20.6 & 16.2 \\
\hline 3 & Russia & 17.0 & 13.4 \\
\hline 4 & USA & 12.0 & 9.4 \\
\hline 5 & Columbia & 6.6 & 5.2 \\
\hline 6 & SAR & 6.2 & 4.9 \\
\hline 7 & Canada & 5.8 & 4.5 \\
\hline 8 & Netherlands & 3.9 & 3 \\
\hline 9 & Mongolia & 2.8 & 2.2 \\
\hline 10 & China & 0.8 & 0.6 \\
\hline
\end{tabular}

Source: compiled by authors based on [2].

The export market for coal is unconditional leaders: Australia and Indonesia. Indonesia has emerged as the leader in coal exports at the expense of rapid growth in fuel consumption in the Asian region. The coal industry of the country is represented mainly by coal for heat generation, and metallurgical coal occupies a rather insignificant part. Absolutely different things are happening with Australian coal, which is $47 \%$ represented by coking coal, which makes it an unconditional leader in the supply of coal for metallurgy. Indeed, the stability of the supply of the country to a large extent depends on the world metallurgical industry. For example, the "Debbie" hurricane, which was in Australia in 2017 , has led to an increase in the price of metallurgical coal, and hence steel.

The cost of imported coal in 2018 amounted to $\$ 152$ billion. The US, which represents an increase of 30\% compared to 2014 ( $\$ 116.9$ billion) (Table 2).

Table 2. World countries -importers of coal in 2018.

\begin{tabular}{|c|l|c|c|}
\hline No. & \multicolumn{1}{|c|}{ Country } & $\begin{array}{c}\text { Volume of imports } \\
\text { of coal, } \$ \text { billion }\end{array}$ & $\begin{array}{c}\text { Share of total exports } \\
\text { of coal, } \%\end{array}$ \\
\hline 1 & Japan & 25.4 & 16.7 \\
\hline 2 & India & 24.6 & 16.2 \\
\hline 3 & China & 19.6 & 12.9 \\
\hline 4 & South Korea & 16.5 & 10.9 \\
\hline 5 & Taiwan & 8.1 & 5.3 \\
\hline 6 & Netherlands & 5.9 & 3.9 \\
\hline 7 & Germany & 5.7 & 3.7 \\
\hline 8 & Turkey & 4.4 & 2.9 \\
\hline 9 & Brazil & 3.4 & 2.2 \\
\hline 10 & Malaysia & 3.2 & 2.1 \\
\hline
\end{tabular}

Source: compiled by authors based on [2].

The recent uneasy environmental situation has forced the authorities to gradually reduce their own production and import more raw materials. That is why Japan, India and China are leaders in importing coal. These countries practically do not extract coal for environmental reasons. At the same time, the share of TPPs in the structure of power generation for them is still very significant, which determines the involvement in the international trade in coal fuels. 


\section{Features of world prices formation for the sale of coal}

Coal is a rather non-standard commodity, and its price varies considerably depending on the caloric content, the presence of impurities and the supply base for each individual producer. The higher the carbon content and the less impurities in the coal, the more expensive it costs. The prices of coal sold on the international market are usually expressed in US dollars per ton or tonne of coal equivalen. In accordance with international rules (Incoterms), different supply bases are allocated: FOB (Free On Board), FAS (Free Alongside Ship), CIF (Cost Insurance and Freight), DAP (Delivered At Place), FCA (Free Carrier). These rules regulate the rights and obligations of the buyer when conducting international trade, as well as determine the moment of transfer of risks from the seller to the buyer. The higher the risks and obligations of the seller in accordance with the basis of delivery, the higher the value of the contract. Prices CIF (value, insurance and freight) are used for import of coal, and prices for FOB (free ship) - exports. The FOB price is the price of the coal itself, plus the cost of transporting from the mine to the port of shipment port in the exporting country. The price of the CIF includes, except for the FOB price, all the costs of international transportation to the destination port of the terminal in the importing country. In the US, instead of FOB, the term "free-to-ship" or FAS is used. The difference lies in the fact that FOB includes the cost of the load, and the FAS does not include. Prices for coal vary depending on its quality, quantity, transportation costs and other conditions. There are two distinct markets - the market for steam coal and the market for coking coal, although they interact and to some extent replace each other. Prices for steam coal are usually adjusted according to calorific values, measured in kilocalories per kilogram (Kcal / $\mathrm{kg}$ ). The standard net calorific value is $6500 \mathrm{kcal} / \mathrm{kg}$.

Among the main price benchmarks in the market for energy coal, futures traded on CME are: ACM (5500 kcal/kg, FOB Newcastle), MFF (5500 kcal/kg, FOB Richards Bay). Data for quotations are taken from the prices of agencies Argus and McCloskey, based on aggregated information on the implementation of operations for the supply of coal.

Over the past few years, electronic commerce has been greatly developed using derivative financial instruments. In addition to physical buyers (power generating companies) and sellers (coalmining enterprises), banks and financial traders take part in coal trading in the financial market or securities market, and the volume of trade in these markets is increasing. It changed the method of trade and the formation of coal prices. Futures contract markets for coal have not yet reached the same stage of development as oil futures markets. At present, payments for coal futures are made in cash in accordance with the published coal price indices (with the exception of NYMEX and ASX). This is mainly due to the small volumes of trading on futures exchanges on coal. However, if final settlements are carried out in accordance with spot prices or indices, futures contracts are tied to the spot market as the settlement time approaches. In addition, one more problem is the transparency of spot indexes.

Prices for all types of coal purchase and sale transactions are determined using the indices defined by the international price agencies. The largest coal derivatives market is formed around API2 (All Publications Index number 2), a price index of CIF steam coal delivered to the ARA area. The second largest is API4, a price index of FOB steam coal at the Richards Bay terminal in South African. In 2001 Global Coal was created by coal producers (Anglo American, BHP Billiton, Glencore and Rio Tinto), end-users (ENEL, EON and J-Power) and others. It is an electronic platform to trade both physical coal and financial products among its members. Global Coal is headquartered in London under the supervision of the UK Financial Services Authority (FSA). In 2002, the Newcastle index is based on FOB steam coal prices at the Newcastle terminal in Australia, aiming at establishing itself as the benchmark for the Asia Pacific steam coal market. An OTC swaps 
market has been formed around it in recent years. Also in 2001, the NYMEX began trading coal futures. By then, US electric utilities were no longer eager to enter into long-term coal supply contracts and preferred more flexible short-term contracts. The list of key indexes for coal is given in Table 3 .

Table 3. Key price indices for coal.

\begin{tabular}{|l|l|l|}
\hline \multicolumn{1}{|c|}{ Index } & \multicolumn{1}{|c|}{ Characteristic } & \multicolumn{1}{|c|}{ Who publishes } \\
\hline API2 & $\begin{array}{l}\text { CIF Amsterdam, Antwerp, is used to } \\
\text { import energy coals to Europe }\end{array}$ & $\begin{array}{l}\text { Argus Media, HIS } \\
\text { McCloskey }\end{array}$ \\
\hline API4 & $\begin{array}{l}\text { FOB Richards Bay (PORT) } \\
\text { Used for the exporter of steam coal from } \\
\text { South Africa }\end{array}$ & $\begin{array}{l}\text { Argus Media, HIS } \\
\text { McCloskey }\end{array}$ \\
\hline Newcastle index & $\begin{array}{l}\text { FOB Newcastle (Australia) } \\
\text { Used for the export of Australian steam } \\
\text { coal }\end{array}$ & Global Coal \\
\hline $\begin{array}{l}\text { Central Appalachians } \\
\text { PAPP) } \\
\text { Powder River Pool }\end{array}$ & Prices for coal produced in the USA & The agency "Platts" \\
\hline API5 & $\begin{array}{l}\text { The price index for Australian charcoal is } \\
5500 \mathrm{kcal} / \mathrm{kg}\end{array}$ & $\begin{array}{l}\text { Argus Media, HIS } \\
\text { McCloskey }\end{array}$ \\
\hline API8 & $\begin{array}{l}\text { The price of coal with caloric value of 5500 } \\
\mathrm{kcal} / \mathrm{kg}, \text { which is supplied to South China }\end{array}$ & $\begin{array}{l}\text { Argus Media, HIS } \\
\text { McCloskey }\end{array}$ \\
\hline
\end{tabular}

Source: compiled by authors based on [3].

The table shows that the world coal market is divided into two major segments: AsiaPacific and Atlantic. The current situation on the world market is characterized by exceeding the supply of coal over demand, which led to a long decline in prices, and a negative impact on exporting companies. The effective functioning of coal industry enterprises is due to a large variety of factors, including balanced management of the global value chain, which are most often formed within the framework of the export-oriented model of development of countries [4]. However, in the period from 2016 on the world market of coal there is a rise in prices, with some types of raw materials they have grown 2 times (Fig. 2).

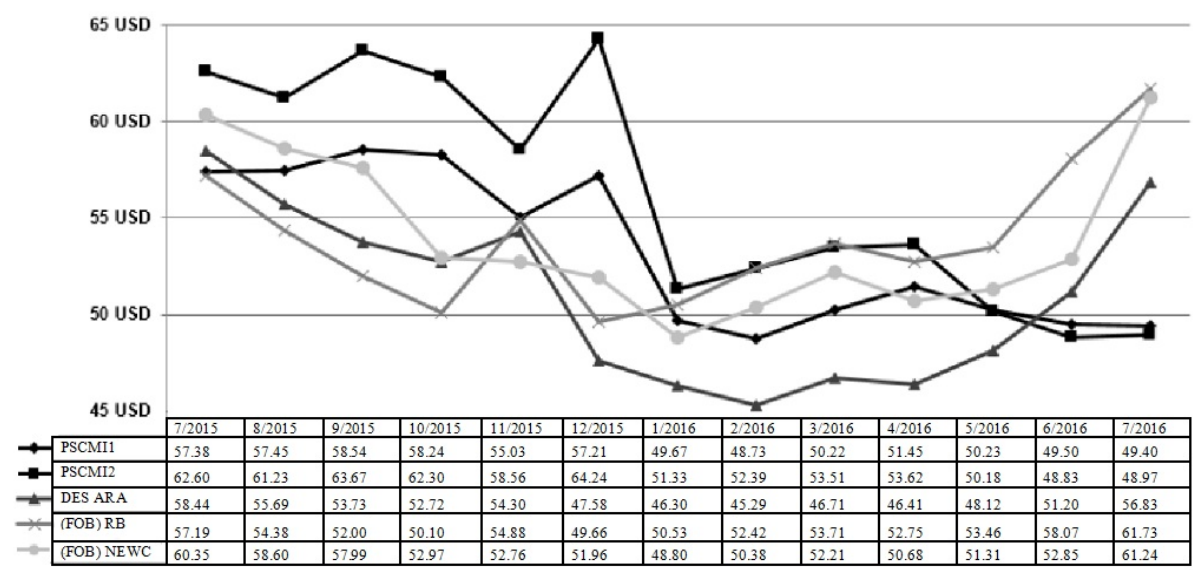

Fig. 2. The dynamics of coal prices.

Source: compiled by authors based on [3]. 
In ports of Northwest Europe, prices have risen from 47 dollars per ton in 2015 to 87 dollars in 2016, and in the Russian port of the East for the same period - from 53 to 88 dollars per ton. Now the price is set at $50-60$ dollars per tonne of coal, in general, over the past five years, the price drop has almost doubled. Coal gradually loses attractiveness as a kind of fuel. In the United States in recent years, the share of coal generation has decreased from 50 to $32 \%$. China plans to reduce the share of energy generating companies by $67 \%$ by 2020 .

The largest energy agencies do not see the great potential of coal in the long run. The forecast of the Energy Information Administration (EIA) suggests that coal consumption by 2050 will be stagnant. The greatest increase in consumption will come from gas and renewable energy. The amount of electricity produced from coal-fired power plants is declining sharply, falling by around 60 percent by 2030 and by around 95 percent by 2050 . However, production from gas-fired power plants will increase by around 40 percent by 2050. Wind and solar power plants will generate around 44 percent of the electricity in 2050. Around 36 percent of the electricity comes from steerable fossil power plants. The remaining electricity is produced by steerable, renewable energies such as biomass power plants or reservoirs. Demand for electricity will rise by around 17 percent by 2050 . Above all, population growth and more electrification in households will increase the demand for electricity.

Similarly, the Asia-Pacific Economic Cooperation (APEC) holds true. By 2040, coal consumption will grow at the lowest pace among other sources of electricity. Among the leaders of the APEC is gas and renewable energy (Fig. 3).
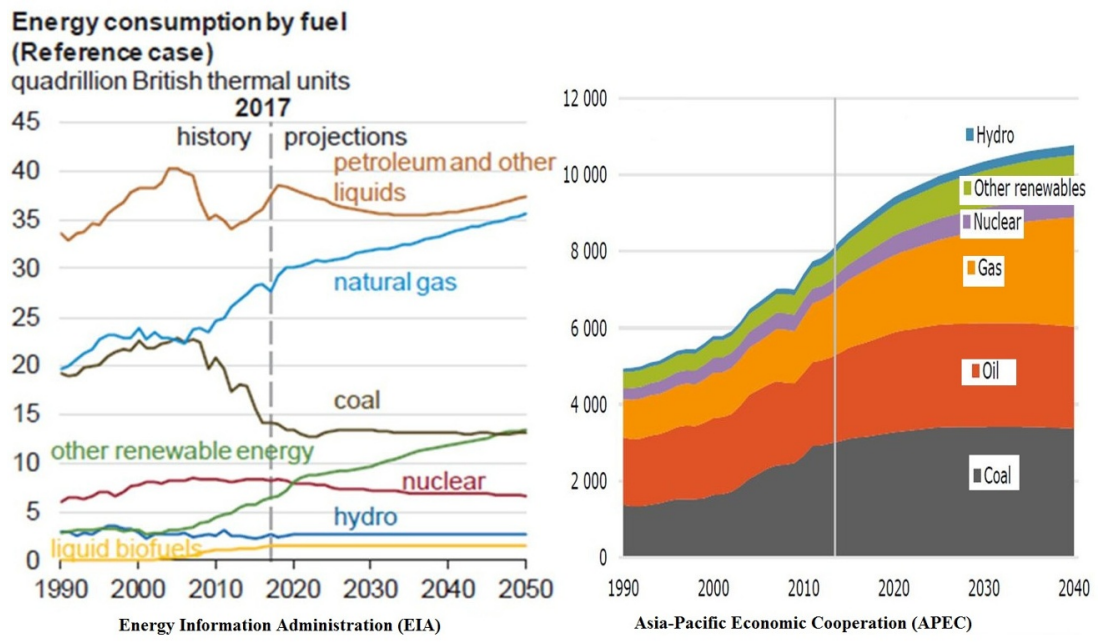

Fig. 3. Long-term forecasting of world consumption of coal.

Source: compiled by authors based on $[5,6]$.

\section{Environmental consequences of coal mining}

The key problem of using coal is the negative impact on the environment. In coal mining, in addition to high explosive hazard, possible emissions of methane damages the ozone layer. No other energy source contributes to emissions of greenhouse gases to the extent that coal. The use of coal leads to serious pollution of the environment (Fig. 3):

1) release of $\mathrm{CO}_{2}$ in the combustion of coal enters the atmosphere, reacts with water and forms sulfuric acid (the basis of acid rain); 
2) burning coal into the air weighing suspended particles that affect the respiratory system of the organism;

3) nitrogen oxides are released;

4) coal produced from the coal combustion contains small amounts of mercury, arsenic, lead;

5) coal waste contains some radioactive substances;

6) coal combustion is high in carbon dioxide ( $1 \mathrm{~kg}$ of coal is almost $3 \mathrm{~kg}$ of $\mathrm{CO}_{2}$ ), which determines the greenhouse effect on the planet.

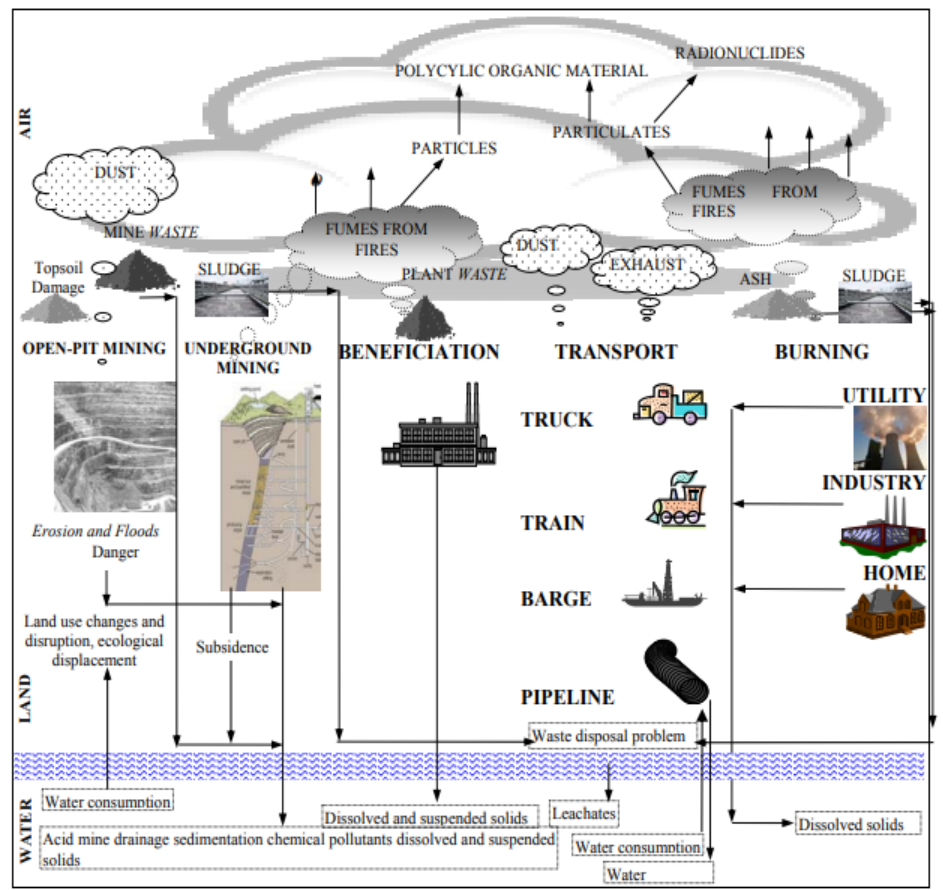

Fig. 4. Negative influence of coal mining on ecology.

Source: compiled by authors based on [7].

Surface coal mining operations require large areas of land to be temporarily disturbed creating a number of environmental challenges, including soil erosion, dust, noise, water pollution, and impacts on local biodiversity [8-10].

Coal mining causes direct and indirect damage to human health. The European Register of Emissions and Transfer of Pollutants includes 53 pollutants that, as a result of the operation of coal stations fall into the air, water and soil.

Coal is becoming less popular in developed countries against the backdrop of trends in environmental protection and the promotion of renewable energy sources. One of the types of alternative energy is coal from waste technology-based, allowing to process food waste into fuel $[11,12]$. This trend is further exacerbated by state subsidies for green energy [1315]. It is cheaper to put into operation wind turbines and solar panels than to support the work of a coal power plant in some areas of the USA.

In order to develop the coal sector and eliminate environmental problems, the European Union has proposed five closely related ideas. Firstly, creation of a fully integrated internal energy market, which will facilitate trade in electricity between member countries. Secondly, increasing energy efficiency by reducing electricity, heat and fuel consumption, which will save 200 billion euros per year by 2020 . The third aspect is climate protection, 
which envisages the reform of the emission trading scheme, the growth of power generation by means of RES and the electrification of the transport system. The fourth direction is research and innovation in the field of low carbon technologies. The fifth direction is the "decarbonising the EU economy". The European Union has committed itself to reducing its greenhouse gas emissions by $80-95 \%$ by the year 2050, and it hopes to break the link between economic growth and the growth of energy sector emissions, with positive employment implications.

Many coal-fired generating stations in the world have now signed up to the tough new limits on emissions required under the LCPD [16]. The fact that they are prepared to make or have already made, in some casessignificant investment in FGD (Flue Gas Desulphurisation) technology shows a real commitment to ensuring a long term future for coal-fired generation in the UK. Also, a number of coal-fired generating companies have shown interest in retrofitting improved combustion technologies to their existing plant, or in building new coal-fired power stations, equipped from the outset with state-of-the-art, high efficiency generating sets and designed to accept the next generation of cleaner coal technology as it comes to the market, which requires achieving the optimum capital-labor ratio to increase the rational use of production assets in domestic enterprises, which are characterized by relative excess equipment with high wear [17].

\section{Conclusions}

Coal is an important strategic raw material for world energy. World demand for coal in the near future will increase, first of all, by increasing damands in cheap energy in developing countries.There is a tendency towards a decrease in coal extraction and exports in connection with the transition to alternative energy in developed countries, on the contrary.

Prices for coal are regional in nature, ie they vary considerably in different regions of the world. The cost of coal in world markets is now at 50-60 dollars per ton, depending on the region and quality of coal. In the near future no sharp changes in the price situation are expected, as there are many producers in the global coal market capable of working with sufficient profitability at all costs.

Further development of the industry will depend on a number of factors, in particular: ensuring the renewal of fixed assets of coal enterprises, the introduction of exchange trading in coal products, the elimination of loss-making mines and the completion of the privatization of state-owned share of authorized capital in enterprises with coal-generating capacity of the power industry.

Further development of the industry will depend on a number of factors, in particular: ensuring the renewal of fixed assets of coal enterprises, the introduction of exchange trading in coal products, the elimination of loss-making mines and the completion of the privatization of state-owned share of authorized capital in enterprises with coal-generating capacity of the power industry.

We would like to thank National University of Water Environmental and Engineering for assistance in collecting the data presented in this study.

\section{References}

1. Influencemap. (2017). Who Owns the World's Coal. A forensic look at the shareholders of the global thermal coal business. Retrived from https://influencemap.org/finance-map

2. Wamsted, E., Feaster, S., \& Schlissel, D. (2019). Coal Outlook 2019. IEEFA

3. Energy Charter Secretariat. (2010). The price of energy: the formation of international coal prices. Brussels, Belgium. 
4. Koval, V., Duginets, G., Plekhanova, O., Antonov, A., \& Petrova, M. (2019). On the supranational and national level of global value chain management. Entrepreneurship and Sustainability Issues, 6(4), 1922-1937. https://doi.org/10.9770/jesi.2019.6.4(27)

5. International Energy Agency. (2019). Energy Outlook 2019 with projections to 2050. United States.

6. APERC. (2016). APEC Energy Demand and Supply Outlook (6th Edition). Asia Pacific Energy Research Centre. Tokyo.

7. Heinrich-Böll-Stiftung. (2016). Coal Atlas: Facts and figures on a fossil fuel. Friends of the Earth International. Berlin: Phoenix Print GmbH, Würzburg.

8. Dryzhenko, A., Moldabayev, S., Shustov, A., Adamchuk, A., \& Sarybayev, N. (2017). Open pit mining technology of steeply dipping mineral occurences by steeply inclined sublayers. International Multidisciplinary Scientific GeoConference Surveying Geology and Mining Ecology Management, SGEM, 17(13), 599-606. https://doi.org/10.5593/sgem2017/13/s03.076

9. Zhu, Q., Zhang, Z., Li, R., Lai, K. K., Wang, S., \& Chai, J. (2014). Structural analysis and total coal demand forecast in china. Discrete Dynamics in Nature and Society, (1), 1-10. https://doi.org/10.1155/2014/612064.

10. Kalybekov, T., Rysbekov, K., \& Zhakypbek, Y. (2015). Efficient land use in open-cut mining. New Developments in Mining Engineering 2015: Theoretical and Practical Solutions of Mineral Resources Mining, 287-291. https://doi.org/10.1201/b19901-51

11. Koval, V., Mikhno, I., Hajduga, G., \& Gaska, K. (2019). Economic efficiency of biogas generation from food product waste. E3S Web of Conerences, (100), 00039. https://doi.org/10.1051/e3sconf/201910000039

12. Bondarenko, V., Lozynskyi, V., Sai, K., \& Anikushyna, K. (2015). An overview and prospectives of practical application of the biomass gasification technology in Ukraine. New Developments in Mining Engineering 2015: Theoretical and Practical Solutions of Mineral Resources Mining, 2732. https://doi.org/10.1201/b19901-6

13. Zhironkin, S., Khloptsov, D., Skrylnikova, N., Petinenko, I., \& Zhironkina, O. (2018). Economic Principles of Mining Region Sustainable Development. E3S Web of Conferences, (41), 04010. https://doi.org/10.1051/e3sconf/20184104010

14. Melody, S.M., \& Johnston, F.H. (2015). Coal mine fires and human health: What do we know? International Journal of Coal Geology, (152), 1-14. https://doi.org/10.1016/j.coal.2015.11.001

15. Höök, M., \& Aleklett, K. (2010). Trends in U.S. Recoverable Coal Supply Estimates and Future Production Outlooks. Natural Resources Research, 19(3), 189-208. https://doi.org/10.1007/s11053-010-9121-1

16. Patzek, T.W., \& Croft, G.D. (2010). A global coal production forecast with multi-Hubbert cycle analysis. Energy, 35(8), 3109-3122. https://doi.org/10.1016/j.energy.2010.02.009

17. Yankovyi, O., Goncharov, Yu., Koval, V., \& Lositska, T. (2019). Optimization of the capitallabor ratio on the basis of production functions in the economic model of production. Naukovyi Visnyk Natsionalnoho Hirnychoho Universytetu, (4), 206-212. 